\title{
Methylated-DNA-Protein-Cysteine Methyltransferase
}

National Cancer Institute

\section{Source}

National Cancer Institute. Methylated-DNA-Protein-Cysteine Methyltransferase. NCI Thesaurus. Code C17315.

Methylated-DNA-protein-cysteine methyltransferase (207 aa, $22 \mathrm{kDa}$ ) is encoded by the human MGMT gene. This protein is involved in both repair and dealkylation of DNA. 